\title{
AVALIAÇÃO DA RESISTEENCIA AO RAQUITISMO DA SOQUEIRA E A ESCALDADURA DAS FOLHAS PELO MÉTODO DE VAZÃO DE ÁGUA EM COLMOS DE CANA-DE-AÇÚCAR.
}

MARCELO DE MENEZES CRUZ

Orientador: Prof. Dr. HASIME TOKESHI

Dissertação apresentada à Escola Superior de Agricultura "Luiz de Queiroz", da Universidade de São Paulo, para obtenção do título de Mestre em Agronomia - Área de concentração: Fitopatologia.

$P|R A C| C A B A$

Estado de São Paulo - Brasil

Junho, 1983 
Aos meus pais e sogros,

pelos exemplos,

MEU RECONHECIMENTO.

A Rosa e a Mariana, 
0 autor expressa seus agradecimentos a todos que contribuiram para a realização deste trabalho, especialmente:

Ao Prof. Dr. Hasime Tokeshi, pela eficiente orientação, opor tunidade de treinamento, sugestões e estimulo constante.

A esposa Rosa Maria Prudente Cruz, pelo companheirismo, incentivo e sacrificios, durante o desenvolvimento do presente trabalho.

Ao Programa Nacional de Melhoramento da Cana-de-Açūcar, IAAPLANALSUCAR, pela possibilidade do treinamento e condi ções oferecidas durante a realização deste trabalho.

Ao Engo Agro Jarbas Elias da Rosa 0iticica, ex-Coordenador Regional Nordeste do IAA-PLANALSUCAR, pelas facilidades e apoio concedido.

A Seção de Melhoramento da Coordenadoria Regional Sul do IAA/PLANALSUCAR, e em especial ao Dr. Sizuo Matsuoka, pela excelente colaboração, fornecimento de material e disponibilidade do laboratório.

Aos Professores do Departamento de Fitopatologia da Escola Superior de Agricultura "Luiz de Queiroz", ESALQ-USP e especialmente ao Prof. Dr. Hiroshi Kimati pelos ensina mentos e sugestões.

Ao Engọ Agrọ Dr. Yodiro Masuda pelas correções e sugestões sugeridas . 
Ao Engo Agrọ Norberto Antonio Lavorenti, pelas sugestões e colaboração prestadas nas anālises estatisticas.

A Divisão Agroquīmica da Ciba Geigy Quĩmica S/A e em especial ao Engo Agrọ José Maria Brandão Costa, pela impressão das cópias fotográficas.

Aos Engos Agros Antonio Maria Cardoso Rocha e Carlos Eduar do Lins e Silva Pires, pela solidariedade, convivio e amizade.

Aos colegas de curso e em especial aos Engos Agros Dra. Rosa Maria Valdebenito Sanhueza e Flávio Franco Corte Brilho, pelas sugestões, amizade e apoio recebidos.

A Sra. Maria do Cärmo Maluli Delgado, secretāria da Supervi soria de Melhoramento do IAA-PLANALSUCAR, pelos auxílios prestados e pela versão do resumo para o inglés.

Ao Prof. João Ribeiro Lemos, pela revisão de portugués.

Às bibliotecárias Lucia B. de Melo e Helena Cristina do V. Pimentel, pela revisão da citação bibliográfica.

Ao Sr. Luiz Omena de Lucena, pelos trabalhos datilográficos.

Ao Sr. Pedro da Silva, funcionārio do Departamento de Fitopatologia da ESALQ, pela colaboração nos trabalhos de campo e laboratório. 


\section{İNDICE}

Pāg.

1. INTRODUÇAO . . . . . . . . . . . . . . . . . I

2. REVISAO DE LITERATURA. . . . . . . . . . . . . . 4

2.1. Agente Causal............ . . 4

2.2. Mētodos para diagnose... . . . . . . 8

2.2.1. Diagnose através de reprodução dos sin tomas.............. . 9

2.2.2. Diagnose através de testes quỉmicos e biológicos............. . . 11

2.2.3. Diagnose através de testes serológicos 12

2.2.4. Diagnose através de microscopia... . 14

2.3. Isolamento da bactéria. . . . . . . . . 16

2.4. Testes para seleção de variedades resistentes 17

3. MATERIAL E METODOS ............... 21

3.1. Obtenção do inōculo e inoculação. . . . . . 21

3.2. Avaliação da resistência ao raquitismo da soqueira (RS) e a escaldadura das folhas (EF)pe 10 método de vazão de āgua. . . . . . . . 23

3.3. Contagem dos vasos funcionais do xilema... 24

4. RESULTADOS. . . . . . . . . . . . . 26

4.1. Avaliação da resistência ao raquitismo da soqueira (RS) e a escaldadura das folhas (EF) pelo método de vazão de āgua. . . . . . . 26

4.2. Correlação entre a vazão de água e número de vasos funcionais do xilema. . . . . . . 28

5. DISCUSSAO. . . . . . . . . . . . . . 31

5.1. Avaliação da resistência ao raquitismo da soqueira (RS) e a escaldadura das folhas (EF) pelo método de vazão de āgua. . . . . . .

5.2. Correlação entre a vazão de āgua e número de vasos funcionais do xilema. . . . . . . . 34

6. CONCLUSOES. . . . . . . . . . . . . . . . . 40

7. Literatura CitAdA. . . . . . . . . . . . 42 


\section{AVALIAÇÃO DA RESISTÉNCIA AO RAQUITISMO DA SOQUEIRA E A ESCALDADURA DAS FOLHAS PELO MÉTODO DE VAZÃO DE ÁGUA EM COLMOS DE CANA-DE-AÇŪCAR.}

MARCELO DE MENEZES CRUZ

HASIME TOKESHI

Orientador

RESUMO

Este trabalho teve a finalidade de dar prosse guimento aos estudos de avaliação de resistência ao Raquitis mo da Soqueira (RS) pela vazão de água em colmos de cana-deaçūcar e avaliar a interferéncia da Escaldadura das Folhas (EF), causada por Xanthomonas albilineans (Xa) no método em es tudo.

objetivando a correlação entre a vazão de água e o número de vasos funcionais do xilema, estes foram colori dos com safranina e fotografados em diapositivos, para a con tagem em projeção.

os resultados obtidos mostraram que o método da vazão de água em colmos de cana-de-açūcar ē eficiente, prático e mais preciso do que o método da avaliação pela pró dução no campo.

Por este método, as variedades CB47-355, IAC48/65

e IAC51/205 podem ser consideradas tolerantes e as CB41-76 e 
NA56-79 apresentaram suscetibilidade ao RS.

As variedades CB41-76, CB47-355 e NA56-79 apre sentaram correlação positiva entre vazão e nūmero de vasos funcionais do xilema, não ocorrendo o mesmo com a IAC48/65 e IAC51/205, confirmando que apenas o nümero de vasos funcionais e anatomia vascular não são suficientes para explicar as diferentes reações de resistēncia ao RS.

Foi possivel observar que EF pode interferir na avaliação de resistēncia ao RS e que a EF apresenta um mecanismo diferente de patogenicidade, pois, ocasiona um aumento de vazão no xilema, provavelmente devido à desintegração das paredes celulares do xilema e tecido parenquimatoso adjacente.

Pela coloração dos vasos funcionais, demonstrou-se que o tratamento térmico $\left(50,5^{\circ} \mathrm{C} / 2\right.$ horas $)$ não apre senta eficiēncia total no controle do RS, pois foi possivel detectar touceiras contaminadas provenientes de rebolos cura dos pela termoterapia. 
EVALUATION OF RESISTANCE TO RATOON STUNTING DISEASE AND LEAF SCALD THROUGH WATER FLOW IN SUGARCANE STALKS

MARCELO DE MENEZES CRUZ

HASIME TOKESHI

Adviser

\section{SUMMARY}

The objective of this work was to carry on
studies of evaluation of resistance to Ratoon Stunting
Disease (RSD) by water flow in sugarcane stalks and the
interference of Leaf Scald Disease (LSD), caused by
Xanthomonas albilineans $(X a)$.

In order to determine the correlation between water flow and number of functional xylem vessels, these were saphranine dyed and photograph slides were made for to be projected so that the functional vessels could be counted on the screen.

The results obtained showed that the method of water flow through sugarcane stalks is efficient, practical and more accurate than the yield method under field conditions.,

According to this method, varieties CB47-355, IAC48/65 and IAC51/205 may be considered tolerant and CB41-76 and NA56-79 susceptible to RSD. 
Varieties CB4I-76, CB47-355 and NA56-79 showed positive correlation between water flow and number of functional xylem vessels, which was not true for varieties IAC48/65 and IAC51/205. This confirms that only the number of functional vessels and vascular anatomy are not sufficient to explain different resistanc reactions to RSD.

It was observed that LSD : may interfere in evaluation of resistance to RSD, since LSD presents a different mechanism of pathogenicity increasing water flow in stalks, probably due to disintegration of xylem cell walls and adjacent parenchymatous tissue.

By dying functional vessels, it was demonstrated that the hot water treatment $\left(50: 5{ }^{\circ} \mathrm{C}\right.$ for 2 hours $)$ does not completely eliminate RSD. It was possible to detect contaminated stools produced from hot water treated setts. 


\section{INTRODUÇÃO}

A importāncia econōmica e social da cana-deaçūcar acentua-se à medida que as dificuldades econōmicas crescem conjuntamente com a crise energētica mundial. A re cente expansão da agro-indústria sucro-alcooleira estendeu a ārea dos canaviais brasileiros para mais de 3,2 milhões de hectares, elevando a produção de ālcool para 5,8 bilhões de litros. Esta expansão na produção de álcool permitiu a produção de mais 700 mil veículos movidos exclusivamente a $\bar{a} l \operatorname{cool}$ e a adição de $20 \%$ de ālcool em toda a gasolina cons $\underline{u}$ mida no ano 1982. A substituição da gasolina pelo álcool de cana tornou possivel economizar o equivalente a 80.000 bar rís de petrōleo por dia em 1982.

Não obstante o Brasil ser considerado o maior produtor mundial de cana-de-açūcar, a sua produtividade $\bar{e}$ considerada relativamente baixa quando comparada ao poten cial genético de produtividade que a planta oferece. os re cordes de produção de açūcar, por àrea, são pelo menos trēs vezes maiores que as 4,5 a 7,7 tonelada/hectare obtidas atualmente, no Nordeste e em São Paulo, respectivamente. 
Para se atingir a meta governamental de 1985, que é a produção de 8,3 bilhões de litros de ālcool e mais de 9 milhões de tonelada de açūcar, serā necessārio corrigir algumas distorções, obtendo-se um incremento na produtividade .

Entre os fatores que causam baixa produtividade agro-industrial da cana-de-açūcar, destacam-se as doenças e entre estas, sobressai o Raquitisma da Soqueira (RS). Segundo HUGHES (1978), ela estā disseminada por toda região cá navieira do mundo e as avaliações de perdas indicam reduções que oscilam entre 10 a 60\% MATSUOKA (1976) e TOKESHI (1980).

Sendo o RS uma doença que não apresenta sinto mas visuais especîficos, não se detecta a sua ocorrência. A identificação de variedades resistentes constitui um problema difícil que demanda 2 a 3 anos de controle de produção de parcelas sadias e doentes. Além disso, estes resultados podem ser inteiramente mascarados nos anos chuvosos. Como a me todologia de cura das mudas com RS apresenta eficiência parcial, ocorrem contaminações experimentais que alteram os resultados dos testes de produção.

Buscando solucionar os problemas levantados e desenvolver uma metodologia de seleção de variedades resis tentes ao RS, deu-se prosseguimento aos trabalhos desenvolvi dos no Departamento de Fitopatologia da Escola Superior de Agricultura "Luiz de Queiroz", USP, na avaliação de resistēn cia ao RS, pelo método da vazão de àgua em colmos de cana-de açūcar. Esta pesquisa foi realizada com a finalidade de averiguar com maior precisão os resultados obtidos anteriormente, quanto à interferēncia da Xanthomonas azbizineans (Ashby) 
Dowson, agente da Escaldadura das Folhas (EF) nes te método, e a correlação entre número de vasos funcionais do xilema e a vazão de āgua em colmos de cana-de-açūcar com RS. 


\title{
2. REVISÃO DE LITERATURA
}

\author{
2.1. Agente Causal
}

Durante anos, vários pesquisadores relataram como sendo vírus, o agente causal do Raquitismo da Soqueira (RS) da cana-de-açūcar, possivelmente pela dificuldade de se demonstrar a presença de microorganịsmo associado à doença e ainda pela facilidade de disseminação (STEINDL e HUGHES, 1953; HUGHES E STEINDL; 1955; SCHEXNAYDER, 1956; STEIB e FORBES, 1957).

FORBES e LING (1960). utilizando microscopia eletrōnica, observaram a presença de partículas aproximada mente de forma esférica. Posteriormente, LIU (1963) tentou reproduzir os sintomas do RS a partir de inoculações com uma nucleoproteina, obtida de canas infectadas por esta doença, entretanto, não obteve èxito.

GILLASPIE et alii (1966) atravēs de técnica de centrifugação em gradiente de densidade, observaram a presen ça de partículas virais esféricas com alto teor de ácido nuclëico. STEIB e TANTERA (1970) suspeitaram estar o RS asso ciado a um organismo do tipo micoplasma, porém não consegui- 
ram mostrar qualquer efeito no uso de tetraciclina para o controle da doença. GILLASPIE (1970) tambēm afirma que a tetraciclina não elimina a infectividade do agente, afastando a hipōtese de ser um micoplasma e reforça a possibilidade de ser mesmo um vírus a causa do RS.

KHURANA (1.972) sugeriu que o RS podia ser causado por um complexo de pelo menos dois patógenos, um vĩrus e um organismo semelhante a micoplasma, tendo em vista o material do hospedeiro perder a infectividade quando centrifugado, com baixa velocidade e quando tratado termicamente, mas não pela ação de antibiōticos.

Atravēs de fotoeletromicrografia, PLAVSIC-BAN JAC e MARAMOROSCH (1972) revelaram a presença de corpos pleo mórficos no xilema de canas maduras afetadas, semelhantes a uma pequena bactéria ou organismo do tipo micoplasma. MARAMO ROSCH et alii (1973), através de estudos com microscopia ele trōnica, observaram a presença de um microorganismo semelhan te à bactéria ou talvez ricketsia no xilema de plantas infec tadas com o RS.

TEAKLE et alii (1973) ao examinarem extrato do xilema de plantas de cana-de-açūcar afetadas pelo RS, em microscōpio eletrónico, observaram a presença de células de uma pequena bactēria corineforme, comumente Gram positivo e com mesosso mos espiralados e a sugerem como o possivel agente causal do RS. GILLASPIE et alii (1973) confirmaram esta possibilidade atravēs de microscopia de contraste de fase ao examinarem ex sudados do xilema ou caldo extraído de cana-de-açūcar com RS . 
Conforme TEAKLE (1974) o agente do RS è inativado quando exposto a muitos bactericidas quimicos, incluindo clorofórmio, azina de sōdio ou fenol, mas não por antibióticos como tetraciclina ou estreptomicina. Afirma ainda que o agente do RS não é afetado quando exposto a RNase e DNase. Estas propriedades fazem com que provavelmen te não esteja envolvido um vỉrus, um viróide ou micoplasma na etiologia do RS. A pequena bactéria associada ao RS na Austrālia é possivelmente igual ao microorganismo observado em canas doentes, em Porto Rico por PLAVSIC-BANJAC e MARAMO ROSCH (1972), devido às semelhanças nas propriedades por se rem propensas à sedimentação durante a centrifugação, dificuldade na passagem através de filtros bacteriológicos e sensibilidade para bactericidas, mas não a enzimas de áci dos nucléicos (TEAKLE, 1974).

LIU et alii (1974) isolaram um organismo seme Thante a Xanthomonas vascuzorum de feixes vasculares de col mos de cana-de-açūcar afetados pelo RS. TOKESHI et alii (1974) confirmam a hipótese da presença de bactéria em canas com sintomas do RS e afirmam que hā fortes evidencias de que Xanthomonas albilineans seja um dos agentes da doença.

CHEN et alii (1975) utilizaram o mesmo método usado por TEAKLE et alii (1973) e observaram também uma bac téria corineforme associada ao RS, porém diferente do tama nho das bactērias relatadas anteriormente. GILLASPIE et alii (1975) após tentativas de purificação, estudos de microscopia e experimentos com filtração, sugerem que uma pequena bactēria em forma de bastonete, sem mobilidade, estā presen 
te em plantas de cana-de-açūcar com RS. Esta bactēria possui septo, o que indica ser do grupo corineforme. Os autores levantaram ainda a hipōtese de que plantas infectadas com RS favorecem o desenvolvimento de bactērias e que a referida bactéria pode ser consequēncia da infecção.

WORLEY e GILLASPIE (1975) constataram a presen ça de uma bactéria com septo, pertencente ao grupo corinefor me, ao estudarem em microscōpio eletrōnico, finas secções do tecido basal de colmos de um híbrido de sorgo-capim sudão, com sintomas do RS. Na Africa do Sul, BAILEY (1976a) obser vou com microscopia eletrōnica e microscopia de contraste de fase, uma bactéria nos tecidos de cana-de-açūcar, atacados pela doença e com maiores evidências nas variedades suscetíveis ao RS. DAMANN e DERRICK (1976) com o auxilio de micros copia eletrónica, relataram a associação de uma bactéria corineforme em plantas de cana-de-açūcar atacadas pelo RS na Louisiana.

Apesar de muitos trabalhos associarem o RS à uma bactēria, as dimensões exatas do talo, modo de multiplicação e mobilidade, ainda permanecem em controvērsias ( GILLASPIE et alii, 1976b).

DAMANN. (1976) apōs succionar āgua destilada esterilizada, através dos nōs sadios e doentes de cana, observou em microscopia eletrōnica, um organismo com tamanho e mesossomos coloridos, idēntico à bactēria descrita por TEAKLE et alii (1973). Afirma ainda, que somente quando se obti ver cultura pura da bactēria e se comprovar os postulados de Koch, a etiologia do RS serā determinada.

GILLASPIE e BLIZZARD (1976) testaram o efeito 
da penicilina $G$ em caldo de canas infectadas com RS, porém não obtiveram éxitos na inativação. Isto, possivelmente, por que as concentrações utilizadas não foram suficientes para inibir a multiplicação, ou a bactéria não foi sensível ao an tibiōtico testado.

Vários outros pesquisadores, posteriormente, confirmaram a associação de bactēria com o RS. (RICAUD et alii, 1976a; WEAVER et alii, 1977; BAILEY, 1977; CHEN et alii, 1978; RISHI e NATH, 1978; LIU et alii, 1979).

KAO e DAMANN (1978) sugerem estar o RS associa do a uma bactēria da ordem Actiramycetales, isto, por terem observado a presença em microcolónias fillamentosas, de um or ganismo ramificado em extrato dos vasos do xilema de internō dios do colmo de cana-de-açūcar. Quando o estudo foi realiza do com extrato vascular de pedaços do colmo, com um ou dois nōs, as microcolónias não apareciam, surgindo apenas células individuais ou em cadeia, com curtas ramificações. Segundo estes autores, as cēlulas individuais possuem as mesmas :características da bactēria corineforme descrita anteriormen te, associada à doença.

Em pesquisas no Brasil, SUDO (1980) constatou as bactērias Erwinia herbicola e Pseudomonas rubrisubalbi cans em material de cana-de-açūcar, com sintomas característicos do RS e evidenciou a possibilidade do RS, que no momen to é considerado como sendo causado por bactéria, seja na verdade causado por um complexo de bactérias.

\subsection{Métodos para Diagnose}




\subsubsection{Diagnose Através de Reprodução dos Sintomas}

Devido a não apresentação de um sintoma exter no típico para diagnose do RS, vārios trabalhos têm sido relatados, nos quais os autores procuram solucionar o problema apresentando tēcnicas rāpidas e prāticas para uma perfeita identificação desta doença.

Os primeiros trabalhos para diagnose do RS, fo ram baseados nos sintomas de descoloração vascular, relata dos como características da doença, segundo STEINDL ( 1950$)$ e confirmado por HUGHES e STEINDL (1955), HUGHES e STEINDL (1956), ADSUAR e LOPEZ-ROSA, 1962).

Devido ao longo tempo necessārio para a reprodução dos sintomas em cana-de-açūcar, vārias plantas indicadoras foram testadas e sugeridas. HUGHES e STEINDL ( 1956 ) testaram tomate, beringela, Nicotiana glutinosa, Emizia son chifolia, milho, sorgo e trigo, entre outras. STEIB e FORBES (1957) afirmaram que Johnson grass (Sorghum halepense) e miTho podem ser portadores do agente do RS.

SCHEXNYDER (1959) relata ser possivel efetuar o diagnōstico do RS em nōs imaturos na variedade CP36-105, dez a doze semanas apōs a inoculação. GILLASPIE et alii (1966) afirmam que a variedade CP44-101 possibilita fazer a diagnose em nōs imaturos quatro à seis semanas, apōs a inoculação. SINGH (1969) sugere a variedade Co421 como outra variedade indicadora da doença.

MATSUOKA (1971) recomenda a diagnose do RS atravēs do uso de variedades ou hïbridos do capim elefantelP $\underline{e}$ 
ninsetum purpureum), que são mais convenientes do que variedades de cana-de-açūcar. Em estudo posterior, MATSUOKA (1972) assegura que além de $P$. purpureum, outra série de gramineas são hospedeiras do RS, como Echinochloa colonum, e Panicum maximum, entre outros. Em tes tes de patogenicidade, TOKESHI et alii (1974) utilizaram como plantas indicadoras o capim elefante, milho doce e algumas variedades de cana-de-açūcar.

STEINDL e TEAKLE (1974) obtiveram bons resultados com "bana grass", híbrido de Peninsetum purpureum e $P$. americanum. Segundo IRVINE (1975), a variedade CP44-101 quan do adubada com nitrato de amónia ou com adubação completa e mantida na sombra, produz sintomas iniciais tipicos do RS, e que esta expressão de sintomas pode indicar concentração do agente da doença.

WORLEY e GILLASPIE (1975) relataram que os sin tomas do RS em um hỉbrido de sorgo x capim sudão são bastante acurados e são caracterizados pelo murchamento e morte da planta. BECHET (1976) sugere uma série de variedades de cana - de-açūcar como indicadoras do RS e um clone de "bana grass" como promissor hospedeiro e indicador para rápidas diagnoses do RS.

TEAKLE et alii (1978) afirmam que pela aparência, a variedade Q28 ou outras variedades que desenvolvam os sintomas característicos da doença, podem ser usadas para diagnoses rápidas e específicas do RS, em āreas onde esta do ença ocorre normalmente e não existe possibilidade de avalia ção por microscopia eletrōnica ou de contraste de fase.

TOKESHI (1980) relata que artificialmente $\bar{e}$ possīvel infectar em torno de 14 espēcies de gramineas. Em 
trabalhos recentes, SUDO (1980) afirma que o teste do ca pim elefante é inespecífico para a bactēria do RS, reagindo positivamente para diversas bactérias, fungos e leveduras. Conforme TOKESHI (1980), todos estes testes biológi cos são falhos por não serem específicos à bactéria do RS.

2.2.2. Diagnose Atravēs de Testes Químicos e Biolōgicos

FARRAR (1957) desenvolveu um teste quỉmico com a finalidade de diferenciar canas sadias de canas doen tes. Este teste consistia em tratar as secções longitudi nais, obtidas da periferia dos nōs basais de colmos maduros, com perōxido de hidrogēnio a 3\%, combinado com ācido clorídrico hidratado. Em canas sem sintomas, ocorria uma coloração azul-esverdeada, na região do tecido parenquimatoso prōximo aos feixes fibrovasculares, enquanto nada ocorria nos tecidos das canas afetadas.

Conforme ANTOINE (1957), o RS poderia ser diag nosticado por uma técnica colorimétrica, através do uso de 2, 3,5-cloreto trifenil tetrazólio. Este sal, quando em contato com tecido vivo, altera a sua coloração e esta alteração se processa de maneira mais räpida nos tecidos de cana com o RS do que nos tecidos sadios. Entretanto, HUGHES (1958) usou as técnicas descritas por FARRAR (1957) e ANTOINE (1957) e concluiu que nenhum dos testes oferece precisão nos resultados.

Estudos cromatogräficos, desenvolvidos por FI FE e STOKES (1959), mostraram que extrato de folhas de plan tas doentes tinha maior concentração de vārios aminoācidos 
quando comparado com extrato das folhas de planta sadia. En tretanto, os autores sugerem que o método seja mais estudado para melhorar a avaliação e eficiencia das anālises cromatogrāficas para avaliação do RS.

ROTH e WHITEHEAD (1965) realizaram uma técnica, na qual tratavam a parte periférica do colmo com a apli cação de uma solução de nitrato de prata e amônia ou uma so 1 ução a $20 \%$ de hidrōxido de potāssio. A reação consistia nu ma coloração amarela nos tecidos sadios, enquanto nos 10cais onde os feixes fibrovasculares estavam atacados, surgi am estrias avermelhadas no fundo amarelo. Os autores alertam quanto à necessidade de maiores estudos, devido a alguns resultados contraditórios.

\subsubsection{Diagnose Atravēs de Testes Serolōgicos}

GILLASPIE et alii (1966) realizaram trabalhos de purificação do vĩrus tido como provável agente causal do RS, e, em adição a estas pesquisas tentaram desenvolver um anti-soro para este vírus, visando uma possível identificação no laboratōrio e no campo. Em tentativas de purificação, GILLASPIE (1971) produziu anti-soro, para adsorver as prepa rações infectivas de plantas doentes e alternativamente, frações de gama-globulina do anti-soro produzido de plāntulas sadias, foram separadas e usadas para adsorção dos preparados. Nenhum método obteve sucesso e cada um deles redu zia a infectividade. Afirma ainda o autor que o vírus pode ria estar associado com partículas de origem do hospedeiro e ser removido junto com o antígeno do hospedeiro. 
DAMANN et alii (1977) utilizaram a técnica de serologia específica e microscopia eletrōnica (SSEM) e con cluỉram ser este método efetivo em mostrar uma bactéria característica associada com o RS e que tal técnica pode ser usada para diagnosticar esta doença por ser mais sensivel do que microscopia eletrónica com imersão rāpida.

HARRIS e GILLASPIE (1978) relatam o uso de téc nica indireta de anticorpos fluorescentes, usando anti-soro específico para a bactéria corineforme na diagnose do RS. A seguram os autores que o teste é mais sensivel que a microscopia de contraste de fase e pode ser usado rotineiramente com amostras de caldo cru, contendo baixas concentrações da bactéria.

Em estudos realizados com serologia, GILLASPIE (1978a) produziu anti-soro obtido da bactéria associada com o RS, em plantas doentes de cana-de-açūcar ou um híbrido de capim sudão (Sorghum vulgare sudanensis). 0 anti-soro causa um agregado da bactéria e remove a infectividade do caldo ob tido da cana-de-açúcar oú do híbrido do capim sudão infectado pela bactéria. Nenhuma reação serológica foi detectada en tre a bactéria associada ao RS e Corynebacterium flaccumfaciens, C. michiganense ou C. fascians através dos testes de microaglutinação.

Dando prosseguimento a estas pesquisas, GILLASPIE (1978b) afirma ainda que alēm das observações citadas anteriormente, não hā evidēncia de reaçōes homó logas entre a bactēria do RS e Mycobacterium paratubercuLosis, M. tuberculosis, Erwinia amylovora, Agrobacterium tumefaciens, Xanthomonas pruni, streptomyces scabies e 
Streptomyces sp., usando o teste de microaglutinação. Confor me o autor, o anti-soro produzido da bactéria do RS, permite a utilização rápida e econōmica para diagnósticos serológicos, fazer determinações serológicas relacionados entre a bactéria e outros organismos e auxiliar na tentativa de cultivar artificialmente o organismo causal do RS.

GILLASPIE e HARRIS (1978) sugerem um método de seleção para resistência ao RS em grande escala, baseados no teste ELISA (The Enzyme Linked Immunosorbent Assay), em que a intensidade do desenvolvimento da coloração é diretamente relacionado com o nümero de bactéria presente na amostra. 0 teste ELISA detectou em torno de $4 \times 10^{6}$ células por milililitro ou em torno de trēs bactérias por campo de microscopia - de contraste de fase. Em trabalhos posteriores, GILLASPIE e HARRIS (1979), levantam possíveis limitações do método, como baixa sensibilidade, alta absorção de fundo e resultados inconsistentes.

\subsubsection{Diagnose Através de Microscopia}

Depois de PLAVSIC-BANJAC e MARAMOROSCH

(1972) terem observado corpos pleomórficos (bactéria) nas xilema de canas, com RS, através de exames em microscópio eletrónico e eletromicrografia, vārios autores sugeriram a mesma pos sibilidade. (MARAMOROSCH et azii, 1973; TEAKLE, 1973; CHEN, 1975; WORLEY e GILLASPIE, 1975).

GILLASPIE et azii (1973) e STEINDL (1976) afir mam que o RS pode ser diagnosticado através do exame de exsu datos do xilema, empregando-se microscopia de contraste de 
fase ou campo escuro, e que estes métodos são mais acessíveis, menos dispendiosos, fáceis e rāpidos, do que microscopia eletrōnica.

BALLEY (1976a) afirma que exames de bactérias pela microscopia de contraste de fase, em infusão de tecido contaminado, parece ser fácil e vantajoso para a diagnose do RS, principalmente em variedades que não apresentam sintomas nodais conspícuos e também para confirmar diagnose baseada em sintomas nodais. Entretanto, esta técnica tem limitações quando a diagnose $\bar{e}$ feita em tecidos de canas jovens que apresentam poucas bactérias.

GILLASPIE et alii (1976a) estudando clones resistentes e suscetiveis inoculados com RS, comprovaram que o caldo bruto dos clones suscetíveis apresentavam um maior nū"mero de bactéria, em relação ao caldo dos clones resistentes. Desta forma, os autores afirmam que a correlação negati va entre nīvel de resistência ao RS e o número de bactēria no suco do xilema indicam que o método da microscopia de contraste de fase pode ser vantajoso para seleção de variedades resistentes ao RS.

Segundo RICAUD et alii (1976b) o organismo associado ao RS é facilmente distinguido das outras bactérias contaminantes, pela técnica da microscopia de campo escuro, devido as suas formas características e sua morfologia comumente filiforme. BAILEY (1977) em estudos com microscopia de contraste de fase, demonstrou existir uma relação direta entre severidade de reações das variedades afetadas pelo RS e o número de bactérias observadas em preparação de tecidos de 
todas as partes das plantas. Entretanto, devido ao baixo núme ro de bactérias observadas em tecidos da parte apical do colmo e em tecidos de colmos jovens, torna-se necessārio o uso de seç̧ões de colmos maduros, para uma maior segurança na diagnose .

Um método para extração da seiva do xilema dos colmos de cana-de-açúcar usando pressão positiva, foi descrito por RICHARDSON (1978) na qual obtém-se um elevado nūmero de bactērias, sem a necessidade de centrifugação, fazendo os exames diretamente em microscópio de contraste de fase. Utili zando-se este método, as estruturas ramificadas e as protuberāncias da bactéria podem ser observadas através da microscopia de contraste de fase.

KAO e DAMANN (1978) utilizando microscopia de contraste de fase, contraste de interferēncia e eletrônica em pesquisas, tentaram a identificação do agente causal do RS.

TEAKLE et alii (1979) recomendam o uso da técni ca de coloração negativa com fosfotungstato de sódio para microscopia eletrónica, porém afirmam que provávelmente o tamanho da bactéria associada ao RS é bem maior do que se observa através desta técnica. Entretanto, ao usarem acetato de urani la ou telas umedecidas com a suspensão da bactéria sem corante, o talo bacteriano aproximou-se ao tamanho real.

Recentemente, KAO e DAMANN (1980) observaram a presença da bactéria associada ao RS através de estudos em mi croscopia eletrōnica de varredura. 
DAVIS et alii (1980) isolaram de cana-de-açūcar com RS e capim bermuda (Cynodon dactizon), uma pequena bactēria corineforme, semelhante ao agente do RS. Ambos os isolados foram multiplicados em cana-de-açūcar e em capim bermuda, entretanto, o isolado de capim bermuda não causou sintomas de RS em cana-de-açūcar, porēm o desenvolvimento do capim bermuda foi retardado pelos dois isolados.

Conforme GILLASPIE et alii (1981), a bactéria do RS de cana-de-açūcar foi isolada e cultivada em meio arti ficial e sua patogenicidade foi demonstrada em cana-de-açūcar e em um híbrido de sorgo e capim sudão.

Mais recentemente, LIAO e CHEN (1981), afirmam ter cultivado com sucesso, em um meio de cultura artificial, uma pequena bactéria corineforme associada com RS da cana-de açūcar. 0 mesmo meio foi também usado para isolar e cultivar uma bactéria semelhante a do RS, presente em capim bermuda. Este meio é diferente do formulado por DAVIS et alii (1980). Ambos os isolados infectaram e se multiplicaram em um híbrido de sorgo e capim sudão, porēm, só o isolado de cana causou sintomas de murcha em algumas plantas inoculadas.

\subsection{Testes para Seleção de Variedades Resistentes}

Em cana-de-açūcar, trabalhos preliminares rela tam a possibilidade de ocorrer três tipos de resistências ao RS. STEINDL (1961) a firma que as variedades CP29-116, CP52-68 e Q50 são "tolerantes", podendo ser infectadas, mas geralmen te não apresentam danos significativos e que as variedades 
Q44 e Badila parecem ter "resistência de campo" ou seja, não mostraram infeçãa no campo, mas apresentam pouco desenvolví mento quando inoculadas artificialmente e conforme WISMER (1971), a variedade H60-6909 é "imune", pois não conseguiu a sua infecção com o RS.

Posteriormente, STEINDL (1974) relata que o controle do RS com variedades resistentes não é ainda praticado, entretanto, o controle da doença com variedades tole rantes poderia ser desenvolvido desde que se estivesse prepa rado para conviver com a doença e depender inteiramente destas variedades.

TEAKLE et alii (1975) com base nas informações de STEINDL (1961) e WISMER (1971) e acrescentando algu mas outras variedades, testaram a resistênciá, à passagem de água, em pedaços de colmos apresentando apenas um nō, suspei taram que possivelmente a anatomia vascular estaria envolvida na resistência ao RS. Os a utores levantaram a hipótese de que a resistência do movimento da àgua era paralelo à resistência ao movimento do agente do RS e que isto podia limitar a colonização na planta. Ao estudarem esta hipótese, TEAKLE et alii (1975) comprovaram existir correlação entre a taxa da vazão de água em pedaços de colmo sadio e resistência ao RS, aonde a variedade imune H60-6909 apresentou alta resis tência à doença e ao movimento da água, enquanto as variedades tolerantes CP26-116, Q50 e 60C644 foram moderadamente re sistentes à doença e à vazão de àgua. As variedades suscetíveis demonstraram ter relativamente uma baixa resistência a movimento da āgua. Com a mesma metodologia, foi estudada tam 
bém a propriedade da tinta nanquim passar através dos pedaços do colmo colorindo os feixes vasculares funcionais e os resultados mostraram que variedades imunes com alta resistên cia ao movimento apresentaram poucos feixes vasculares escurecidos, em comparação às variedades suscetíveis de alto flu xo.

VALARINI: (1978) utilizando a metodologia de TEAKLE et alii (1975) modificada, desenvolveu um aparelho de nominado fluxômetro e trabalhando tanto com plantas inoculadas com RS e sadias, concluiu que existe uma correlação entre a diferença da vazão de água em colmos sadios e doentes de cana-de-açúcar e o grau de suscetibilidade. Desta forma, - autor sugere a possibilidade de se avaliar a suscetibilida de de variedades a o RS pela determinação da vazão de água, sendo esta técnica um método rápido, económico e eficiente na seleção de plantas resistentes ao RS.

Conforme VALARINI e TOKESHI. (1980) a avalia ção do fluxo de água em colmos sadios e doentes, sofre inter ferência da pressão de vácuo, localização do nó no colmo e perĩodo de armazenamento, na avaliação da resistência ao RS e que cada variedade deve ser comparada em condições idēnticas.

TEAKLE et alii (1978) em estudos microscópi cos, observaram que variedades resistentes, com taxa baixa de fluxo de àgua, apresentam maior nūmero de ramificações nos vasos metaxilema em comparação com nós de variedades suscetí veis. Ao medir os menores poros das células do metaxilema ob servaram que estes tinham $8 \mu \mathrm{m}$, e eram portanto muito maior do que a bactéria associada ao RS $(0,15$ a $0,32 \mu \mathrm{m} \times 1,0$ a 
$2,5 \mu \mathrm{m})$. Os autores relataram que diferenças anatōmicas não são suficientes para explicar a imunidade frequentemente observada na variedade H60-6909. Como tiloses e gomas são comu mente produzidas pela planta em reação ao agente do RS (STEINDL, 1961), esses mecanismos de defesa podem explicar o bloqueio mais rápido dos pequenos poros das variedades resis tentes do que os grandes poros das variedades suscetiveis. MATSUOKA (1980) sugere um método de seleção de tolerância ao RS através de microparcelas, comparando o peso de plantas tratadas termicamente, consideradas como sadias e plantas inoculadas com RS estabelecidas como doentes.

DOUGLAS (1981) afirma que a anatomia-vascular não é suficiente por si sō para explicar o grau de suscetibí lidade entre as variedades e que aparentemente a quantidade de bactérias nas variedades toterantes é menor do que nas va riedades suscetíveis. Assegura também que o método de medida da vazão de àgua pode se constituir num método simples, segu ro, econômico e rápido para se selecionar variedades resis tentes ao RS. O autor afirma que este método pode ser usado com um grande número de variedades, com um mínimo trabalho e pouco espaço e custos operacionais. 


\section{MATERIAL E MËTODOS}

0 presente trabalho foi desenvolvido no Departamento de Fitopatologia da ESALQ/USP e na Estação Experimen tal Central da Coordenadoria Regional Sul (COSUL) IAA-PLANAL SUCAR.

Foram utilizadas cinco variedades de cana-de açūcar: CB47-76, CB47-355, IAC48/65, IAC51/205 e NA56-79, tratadas termicamente $\left(50,5^{\circ} \mathrm{C} / 2 \mathrm{~h}\right)$, pertencentes ao viveiro primānio de mudas sadias da Estação Central do IAA-PLANALSUCAR, em Araras, SP.

\subsection{ObTEnção do InōCulo e Inoculação}

o inōculo utilizado para o teste com o RS foi caldo bruto da variedade IAC52/326, que apresentava sintomas tîpicos da doença, obtidos através de inoculação artificial. Nas inoculaçōes para testar a escaldadura das folhas foi usada cultura pura de Xanthomonas albizineans (Ashby) Dawson ( $X a)$, agente causal desta doença, cultura esta conservada em meio de Wilbrink mais óleo mineral. 0 isola 
do foi o mesmo utilizado por MASUDA (1980). Esta bactéria foi multiplicada em meio de cultura líquido de Wilbrink modi ficado 2 (W-2) (AKIBA, 1978), em Erlenmeyer de $250 \mathrm{ml}$ conten do $100 \mathrm{ml}$ do caldo que foi incubado por oito dias à temperatura ambiente, sob regime constante de agitação. Esta cultura foi centrifugada a $17.300 \mathrm{~g}$ durante 10 minutos (Centrifuga Sorval SS-4).

Após a centrifugação, o sobrenadante foi des cartado e o precipitado foi ressuspenso em àgua destilada es terilizada, com auxilio de um agitador de tubo de ensaio. A concentração da bactēria foi estabelecida em colorímetro (Baush and Lomb, Spectronic 20) a $580 \mathrm{~nm}$, com uma concentração final de $55 \%$ de transmitāncia equivalente à escola no 3 de McFarland correspondente a aproximadamente $8.10^{8}$ talos bacterianos por ml.

Novecentos colmos de cada variedade, sendo tre zentos para cada um dos tratamentos, RS e EF, foram inoculados através de injeção sob pressão, com seringa hipodérmica, com agulha obliterada na extremidade e com abertura lateral. Em cada colmo, foi injetado cerca de $1,0 \mathrm{ml}$ de inóculo a $5 \mathrm{~cm}$ acima do meristema apical (AKIBA, 1978). As plantas consideradas como testemunhas foram injetadas com āgua destilada es terelizada. os colmos inoculados foram etiquetados com fitas plásticas coloridas para diferenciar os tratamentos que fica ram em sulcos distintos.

A idade das plantas variou em torno de 6 a 7 meses.

Algumas plantas das cinco variedades apresenta ram sintomas crōnicos de EF e a motilidade da bactéria foi 
observada em parte das folhas, baseando-se na tēcnica de iso lamento descrita por AKIBA (1978).

\subsection{Avaliação da Resisténcia ao Raquitismo da Soqueira (RS) e a Escaldadura das Folhas (EF) pelo Método de Vazão de $\bar{A} G U A$.}

A metodologia 'empregada neste trabalho foi baseada no método descrito por TEAKLE et alii (1975), modifica do por VALARINI (1978). O aparelho denominado fluxômetro, utilizado para medir a vazão de água através de colmos de cana-de-açūcar, foi o mesmo usado por VALARINI (1978) e DOU GLAS (1981).

A vazão de àgua foi avaliada em secções dos colmos inoculados, próximo à base, medindo $8 \mathrm{~cm}$ de comprimento, composto de apenas um nó e das partes adjacentes dos internódios, sob uma pressão de vācuo constante de $30 \mathrm{~mm} \mathrm{de} \mathrm{Hg}$, por um periodo de 15 minutos.

A extremidade superior do rebolo foi inserida em uma luva de borracha e encaixada no frasco de vácuo atravēs de um funill metālico intermediārio. A outra extremidade (inferior) foi adaptada em uma outra luva de borracha que permanecia constantemente cheia de àgua destilada, ficando assim o pedaço do colmo invertido em relação ao colmo na planta, permitindo a passagem de água no mesmo sentido da seiva bruta no colmo.

Após as determinações, os pedaços do colmo foram cortados longitudinalmente para exames internos, com a 
finalidade de verificar se as variações da vazão de āgua nos pedaços de colmo estavam correlacionados com sintomas tipicos do RS ou de outras doenças vasculares.

Na época da colheita e avaliação de vazão, as plantas estavam com 18 a 20 meses de idade e tinham recebido os tratos culturais normais.

As avaliações dos tratamentos foram feitas me dindo-se a vazão da āgua $(m 1 / 15 \mathrm{~min})$ em 7 repetições compos tas de 20 amostras cada. 0 delineamento foi 0 inteiramente casualizado e os resultados foram submetidos à análise de va riāncia e teste de Tukey para comparação de médias.

\subsection{Contagem dos Vasos Funcionais do Xilema}

A técnica utilizada para coloração dos vasos funcionais foi a mesma para a avaliação da vazão da āgua des crita anteriormente, sendo que a àgua destilada foi substi tuida pelo corante safranina 0 ou tinta nanquim. 0 tempo sob ação do vácuo foi controlado pelo início da passagem do corante.

Posteriormente, os pedaços dos colmos foram cortados transversalmente no anel de crescimento, próximo a região do nō, e estas seções foram avivadas com o auxîilio de instrumento de corte e etiquetados.

As seç̧ões dos nōs foram fotografadas usando uma cāmara fotogrāfica Nikon AS, com lente Micro-Nikkor 33mm 1:35, em filme diapositivo Fujichrome 100 asa, baseando-se no trabalho de TANIMOTO (1964). 
os vasos funcionais foram contados atravēs da projeção dos diapositivos em quadro magnético, tipo kartro e com escurecimento dos vasos funcionais projetados. no quadro, com pincel marcador para evitar dupla contagem, regis trando-se seu nümero com contadores manuais.

Cada tratamento constou de 8 repetições de uma amostra, em um delineamento estatistico inteiramente casual zadò. Os resultados foram submetidos à anālise de variância e teste de Tukey para comparação de médias. 
4. RESULTADOS

4.1. Avaliação da Resistência ao Raquitismo da Soqueira (RS) e a Escaldadura das folhas (eF) pelo Método de Vazão de $\bar{A}_{G U A}$.

A tabela 1 mostra a vazão mēdia de āgua, em 7 repetições cada uma, representada por 20 colmos, para cada tratamento em 5 variedades de cana-de-açúcar tratadas termicamente e inoculadas com caldo bruto (RS), cultura pura de Xa e plantas testemunhas.

A análise da variancia dos dados apresentados na tabela 2 constatou diferenças significativas, ao nīvel de $1 \%$ de probabilidade entre os tratamentos para as variedades CB41-76, IAC48/65 e NA56-79, e ao nível de 5\% para a varieda de IAC5I/205. 


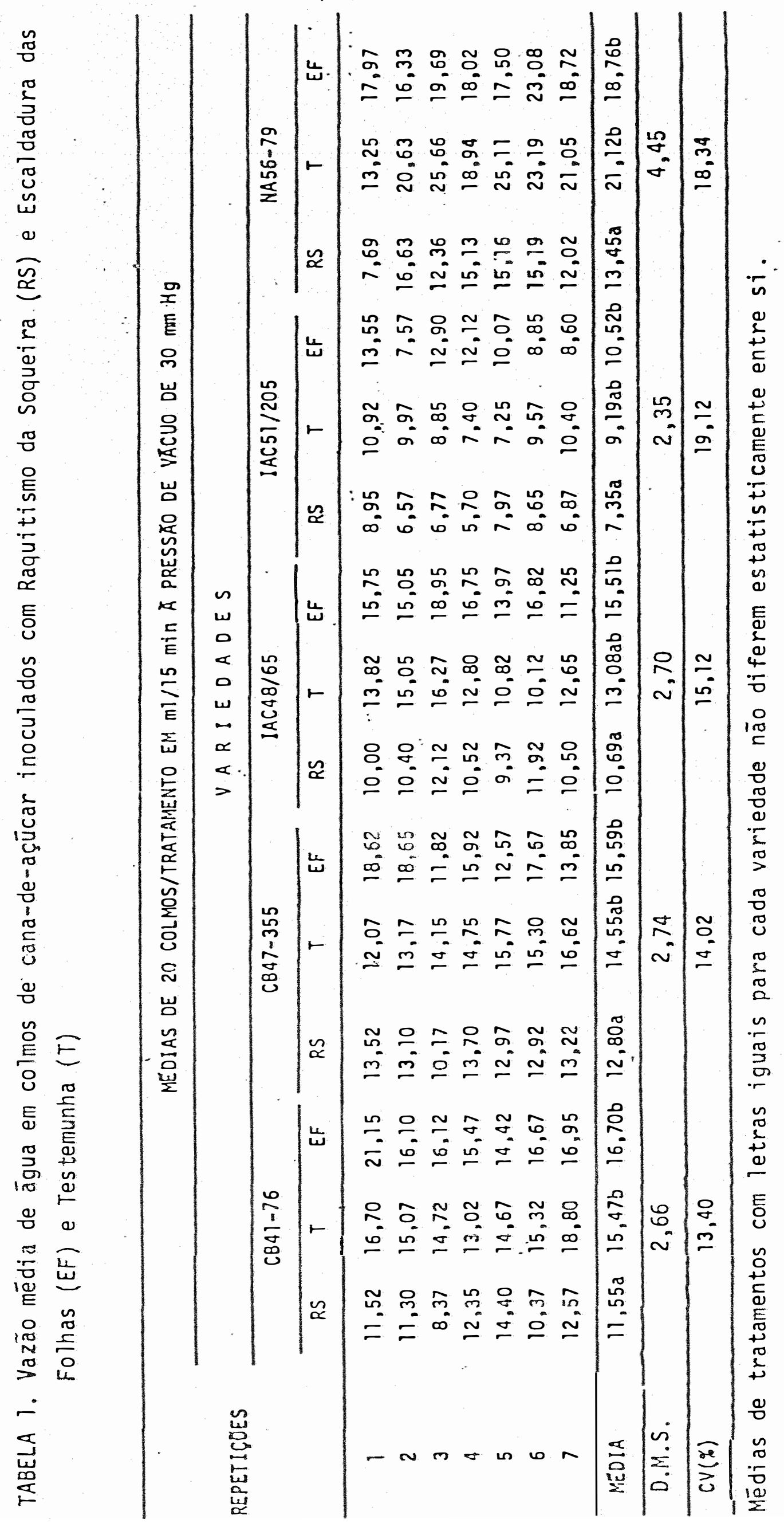


TABELA 2. Anālise da variāncia dos resultados apresentados na Tabela 1. Delineamento inteiramente casualiza do.

\begin{tabular}{lrrrrrr}
\hline $\begin{array}{c}\text { CAUSAS } \\
\text { DA } \\
\text { VARIAÇAO }\end{array}$ & GL & \multicolumn{5}{c}{ QUADRADOS MEDIOS . } \\
\hline $\begin{array}{l}\text { Tratamentos } \\
\text { Resĩduo }\end{array}$ & 2 & $50,5113^{* \star}$ & $13,8733^{\text {ns }}$ & $49,5865^{* *}$ & $17,7223^{*}$ & $107,8542 * \star$ \\
\hline
\end{tabular}

Aplicado o método de Tukey de comparação de mēdias de tratamentos ao nivel de 5\% de probabilidade, verificou-se que em nenhuma variedade os tratamentos EF e testemunha diferiram significativamente entre si.

A testemunha tambēm não diferiu estatisticamen te do tratamento com RS nas variedades CB47-355, IAC48/65 e IAC51/205. Nas demais variedades, esses tratamentos apresentaram diferenças significativas.

Em todas as variedades, a vazão de ãgua em col mos com RS foi menor que os demais tratamentos, diferindo sig nificativamente da vazão mēdia do tratamento com EF.

4.2. Correlação entre a Vazão de Āgua e número de Vasos Funcionais do Xilema.

Verifica-se na Tabela 3 , os dados referentes ao nümero de vasos funcionais do xilema de 5 variedades de cana-de-açūcar, apōs terem sido inoculadas com RS, cultura pura de $X a$ e plantas testemunhas. 


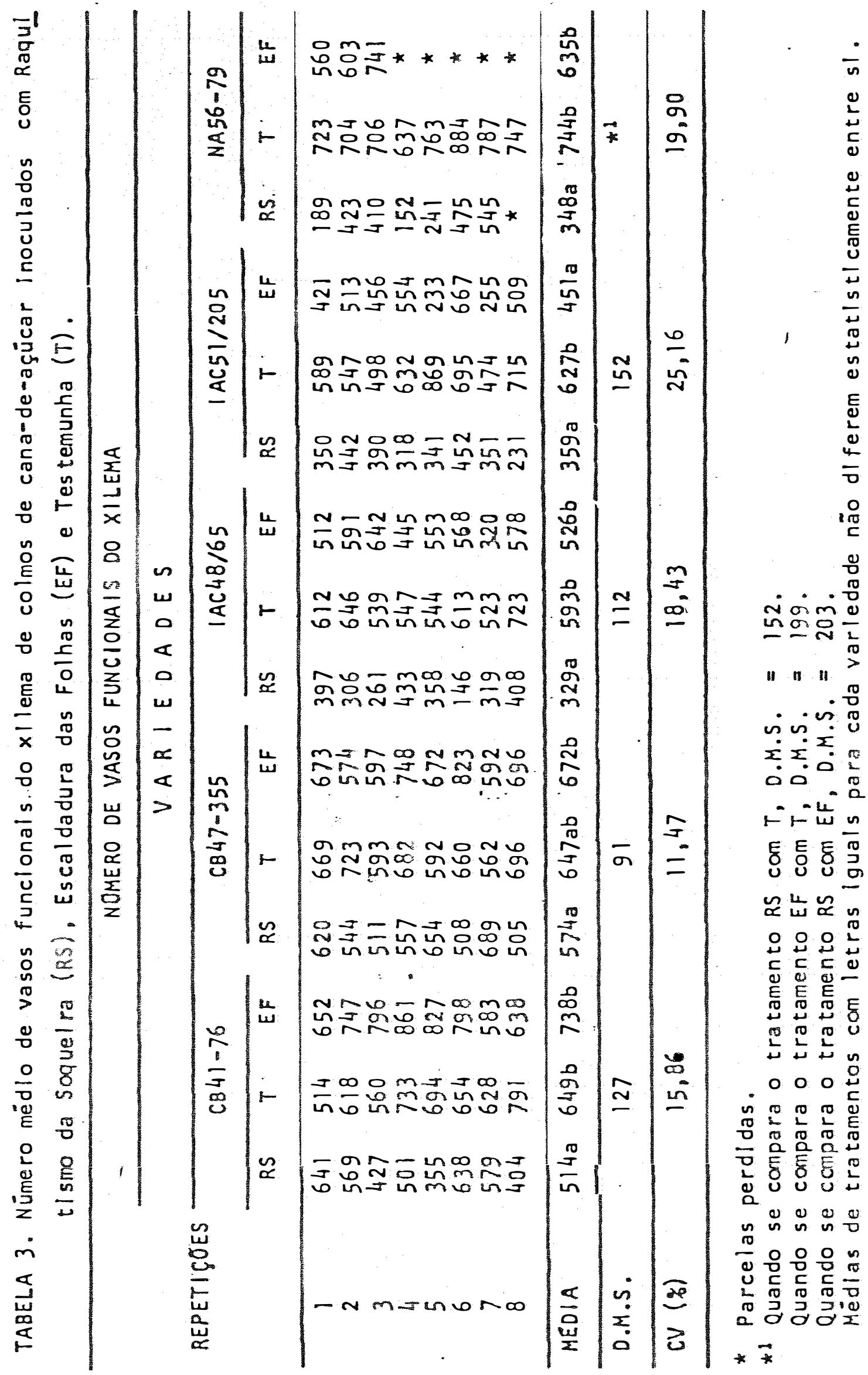


Nas Tabelás 4 e 5 , a anālise da variāncia dos dados apresentados acusou diferença significativa a nivel de $1 \%$ entre os tratamentos, nas variedades CB41-76, IAC48/65, NA56-79 e ao nível de 5\% para a variedade CB47-355,

TABELA 4. Anālise da variāncia dos resultados apresentados na Tabela 3 para as variedades CB41-76, CB47-355, IAC48/65 e IAC51/205. Delineamento inteiramente casualizado.

\begin{tabular}{lrcccc}
\hline \multirow{2}{*}{$\begin{array}{c}\text { CAUSAS } \\
\text { DA } \\
\text { VARIAÇAO }\end{array}$} & GL & \multicolumn{5}{c}{ QUADRADOS MEDI OS } \\
\cline { 3 - 6 } & & CB41-76 & CB47-355 & I AC48/65 & IAC51/205 \\
\hline Tratamentos & 2 & $101315,17 \star \star$ & $20947,7917 \star$ & $151649,29 \star \star$ & $148436,38 \star \star$ \\
Resīduo(s) & 21 & 10105,10 & 5238,9405 & 7911,18 & 14534,27 \\
\hline
\end{tabular}

TABELA 5. Anālise da variāncia dos resultados apresentados na Tabela 3 para variedade NA56,-79. Delineamento intei ramente casualizado.

\begin{tabular}{lrc}
\hline CAUSAS DA VARIAÇAO & GL & QUADRADO MEDIO \\
\hline Tratamentos & 2 & 299893,8 * \\
Resíduo(s) & 15 & 12946,0 \\
\hline
\end{tabular}




\title{
5. DISCUSSÃO
}

5.1. Avaliação da Resistência ao Raquitismo da Soqueira (RS) e a Escaldadura das Folmas (eF) pelo Método de Vazão de $\bar{A} G \cup A$.

\begin{abstract}
0 estudo realizado, nas 5 variedades de cana-de açūcar para avaliar a viabilidade do método da vazão de āgua, mostrou-se bastante efetivo para selecionar variedades tole rantes ao RS, confirmando os trabalhos de VALARINI (1978) e DOUGLAS (1981).
\end{abstract}

Na Tabela,l, verifica-se que nas condições do experimento, as variedades CB47-355, IAC48/65 e IAC51/205 são tolerantes ao RS e as variedades CB41-76 e NA56-79 apresentam-se como suscetíveis.

As reações apresentadas pelas variedades CB41-76, CB47-355, NA56-79 estão de acordo com os resultados obtidos por DOUGLAS (1981). VALARINI (1978) encontrou respostas semelhantes ao testar as variedades CB47-355 e NA56-79, entretan to, este autor não conseguiu detectar diferenças significativas entre a vazão de āgua nos colmos da CB41-76, apesar de 
certa tendéncia, possivelmente por ter feito a avaliação 24 horas apōs a colheita. Conforme o próprio VALARINI (1978) e VALARINI e TOKESHI (1980) o armazenamento do material induz uma queda na vazão de āgua e interfere na avaliação de resistència ao RS, neste método.

Alguns resultados da Tabela 1 estão de acordo com MATSUOKA (1976) que ao estudar a recuperação da produtivi dade de variedadès de cana-de-açūcar, afirma ser a CB41-76 muito sensivel ao RS e com TOKESHI (1980) que considera a variedade CB47-355 tolerante e CB41-76 e NA56-79 como suscetiveis.

Em trabalhos de seleção de tolerāncia ao RS atravēs da produção de colmos (kg/parcela), MATSUOKA (1980) afirma que a variedade CB41-76 é altamente suscetivel ao RS, a IAC51/205 é considerada como tolerante e a CB47-355 como alta mente tolerante, confirmando os resultados obtidos pelo método de vazão de āgua. Ao estudar a variedade NA56-79, MATSUOKA (1980) não detectou diferenças significativas em dois experimentos, entretanto o autor afirma que em uma outra região esta variedade apresentou grandes diferenças de produção entre as parcelas sadia e doente.

Como a resisténcia varietal pode mudar em funçao das condições de fertilidade do solo e regime hídrico, e tendo em vista este trabalho ter sido conduzido no mesmo 1ocal, no qual MATSUOKA (1980) não conseguiu captar diferenças significativas entre as parcelas sadia e doente na variedade NA56-79, o método de vazão de àgua provavelmente ē mais preciso do que o método de avaliação através de microparcelas, 
para diagnósticos de resistēncia ao RS.

Observa-se na tabela 1 que a variedade CB47-355 considerada tolerante apresentou uma vazão de água superior a CB41-76 que é suscetível ao RS. DOUGLAS (1981) obteve dados semelhantes, comparando a CB47-355 com as variedades IAC50/134 e NA56-79, também suscetĩveis. Estes resultados não estão de acordo com TEAKLE et alii (1975) e TEAKLE et alii (1978), que relacionam baixa vazão de āgua, a alto grau de resisténcia. Is to possivelmente, porque nestes trabalhos, os autores fizeram as comparações entre variedades enquanto no presente trabalho, assim como DOUGLAS (1981) as comparações foram feitas entre tratamentos dentro de cada variedade.

Ainda com referéncia a tabela 1 , pode ser obser vado que todas variedades mostraram diferenças marcantes entre as médias de vazão de água entre os tratamentos EF e RS e resultados sem diferenças significativas ao se comparar o tra tamento EF com a testemunha.

Ao tentar avaliar a resisténcia de variedades a EF pelo método da vazão de água, VALARINI (1978) não publicou os resultados obtidos, sugerindo a necessidade de estudos mais apurados para comprovação da eficiēncia do método.

os resultados desta pesquisa que mostrou uma tendēncia de maior vazão nas variedades inoculadas com o agen te causal da EF, sugerem que isto possivelmente ocorreu devido à desintegração das paredes celulares do xilema, obstruí dos por substāncias gomosas produzidas pela bactéria, com a destruição dos tecidos adjacentes ao parênquima do xilema, formando espaços de ar ou lacunas, denominados cavidades 1 iso 
gēnicas, conforme explicam MARTIN e ROBINSON (1961). Por e $\underline{s}$ ta razão e não sendo esta bactéria totalmente controlada pe 10 tratamento térmico (BAILEY, 1976b) é possível haver in terferēncia na avaliação à resistēncia ao RS, caso o material esteja contaminado com Xa. Por esta razão é recomendado o uso de material livre de EF, possível de ser diagnosti cado através de testes serolōgicos (MASUDA,1980) ou aumen tar o nūmero de amostras estudadas com a finalidade de miñ i mizar o possivel erro.

Pelo método de vazão de āgua, foi possível ob servar que os mecanismos de patogenicidade das bactérias cau sais da EF e do RS no interior da planta são diferentes, eliminando a hipōtese sugerida por TOKESHI et alii (1974) co mo sendo Xa um dos prováveis agentes de ambas as doenças.

0 exame interno dos pedaços de colmo não mostraram vasos descoloridos pelo RS nem por outras doenças vasculares, entretanto, TOKESHI (1980), afirma que a ausência de sintomas internos do RS, não assegura sanidade do ma terial.

5.2. Correlação entre a Vazão de $\bar{f}_{i}$ gua e nūmero de Vasos fun CIONAIS DO XILEMA.

A tabela 3 apresenta o número médio de vasos funcionais do xilema de 5 variedades de cana-de-açúcar, onde mostra ter ocorrido uma correlação positiva entre estes números e a quantidade de àgua passada através dos colmos das variedades CB41-76, NA56-79 e CB47-355, com RS. As duas 
primeiras variedades consideradas como suscetíveis ao RS, pe 10 mētodo da vazão de āgua, apresentaram baixo nūmero de vasos funcionais para este tratamento, em relação à testemunha. Nas figuras 1 e 2 são apresentados os vasos funcionais coloridos na NA56-79. A variedade CB47-355 que é tolerante ao RS não mostrou diferença significativa em comparação a testemunha (figuras 4 e 5 ). Estes resultados estão de acōrdo vom VA LARIN I (1978).

0 estudo do nümero de vasos funcionais do xile ma confirma tambēm que o mecanismo da patogenicidade de Xanthomonas albizineans è diferente do agente causal do RS, que alēm de não reduzir a vazão de āgua, não mostra diferenças significativas quando comparados com a testemunha. Estes resultados são mostrados nas variedades NA56-79 e CB47-355, nas figuras 3 e 6 respectivamente.

Entretanto, as variedades IAC48/65 e IAC51/205 não mostraram haver correlação entre os nümeros de vasos fun cionais e a vazão de āgua em colmos de cana-de-açūcar, poss velmente devido a outros mecanismos de resistēncia morfológi ca ou fisiológica destas variedades, confirmando as afirma :ções de TEAKLE et alii (1978) e DOUGLAS (1981) que asseguram que a anatomia vascular não é suficiente por si sō para explicar o grau de resisténcia entre as variedades. Como foi recomendado que o mētodo de vazão de āgua fosse sempre realị zado com um grande nümero de amostras para evitar possíveis erros, interessante se torna efetuar maiores estudos em rela ção aos nümeros dos vasos funcionais do xilema e vazão de $\bar{a}-$ gua, com novos testes e maior nümero de amostras para uma 


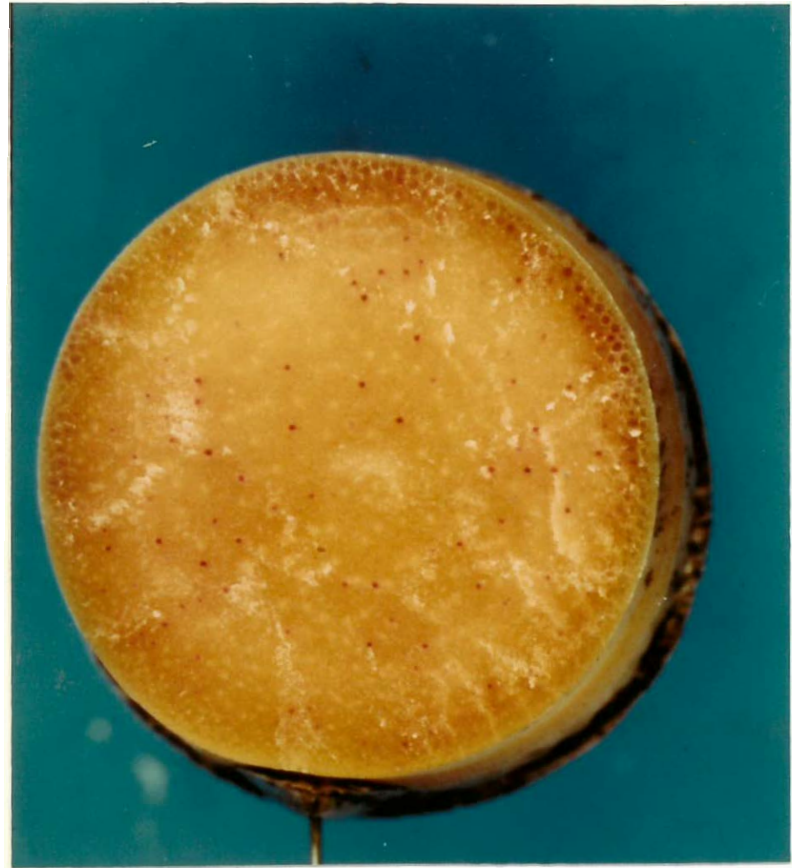

Figura 1 - Com Raquitismo da Soqueira apresentando 189 vasos funcionais.

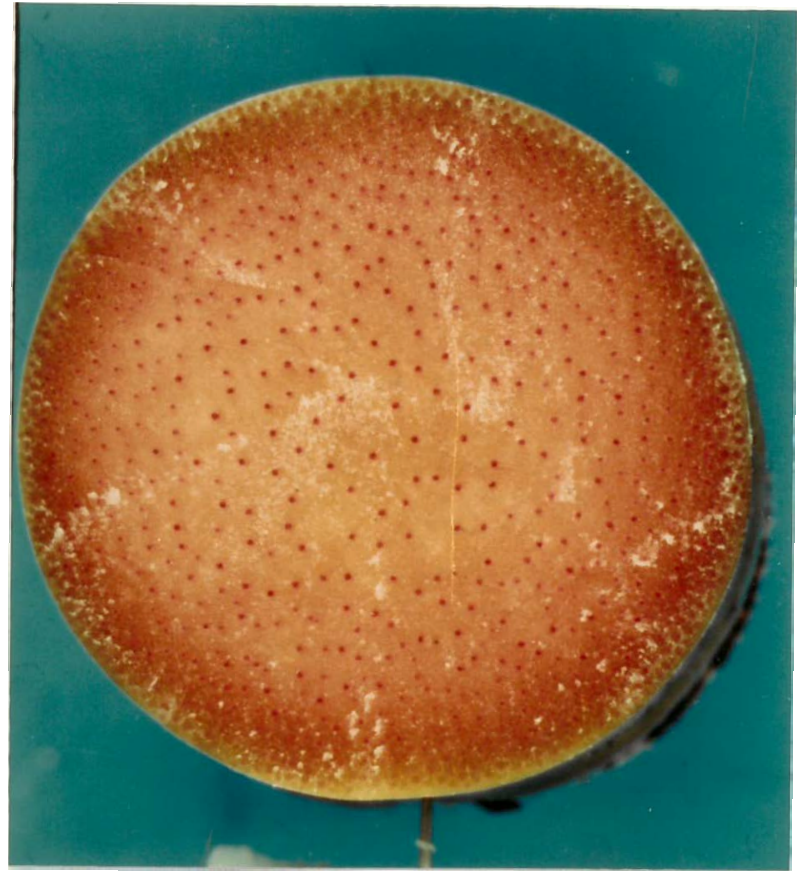

Figura 2 - Testemunha apresentan do 884 vasos funcionais.

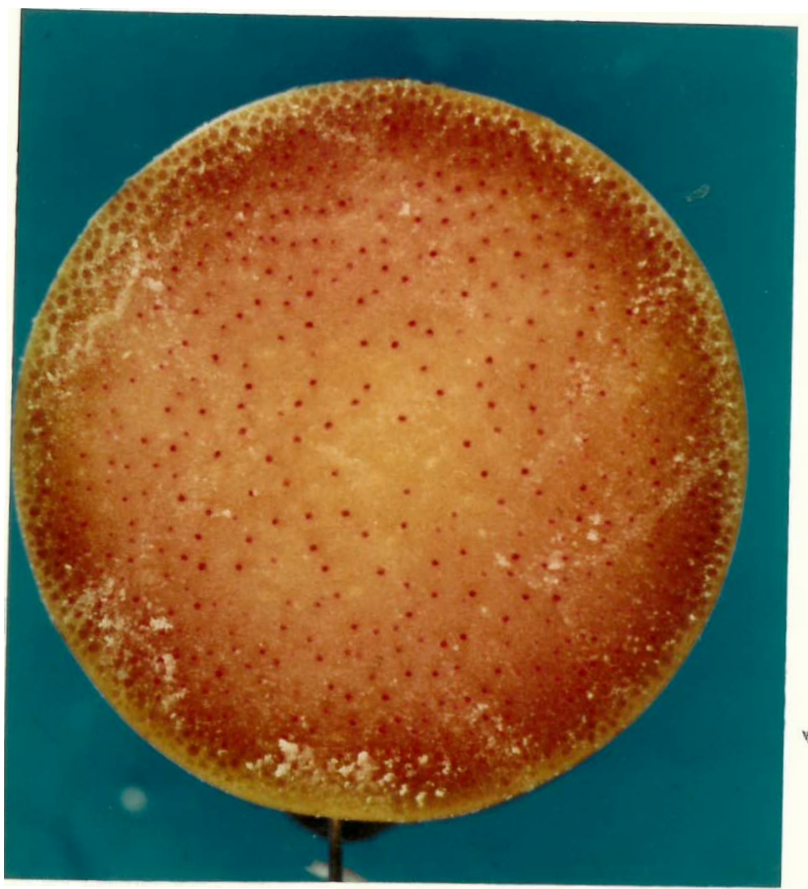

Figura 3 - Com Escaldadura das FoThas apresentando 741 vasos funcio nais. 


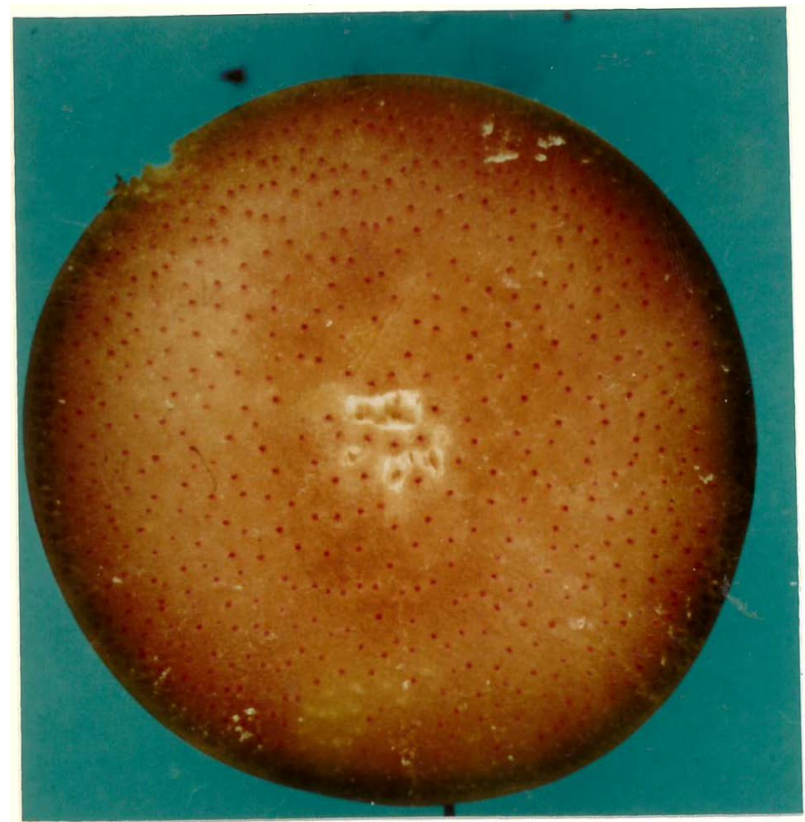

Figura 4 - Com Raquitismo da Soqueira apresentando 689 vasos funcionais.

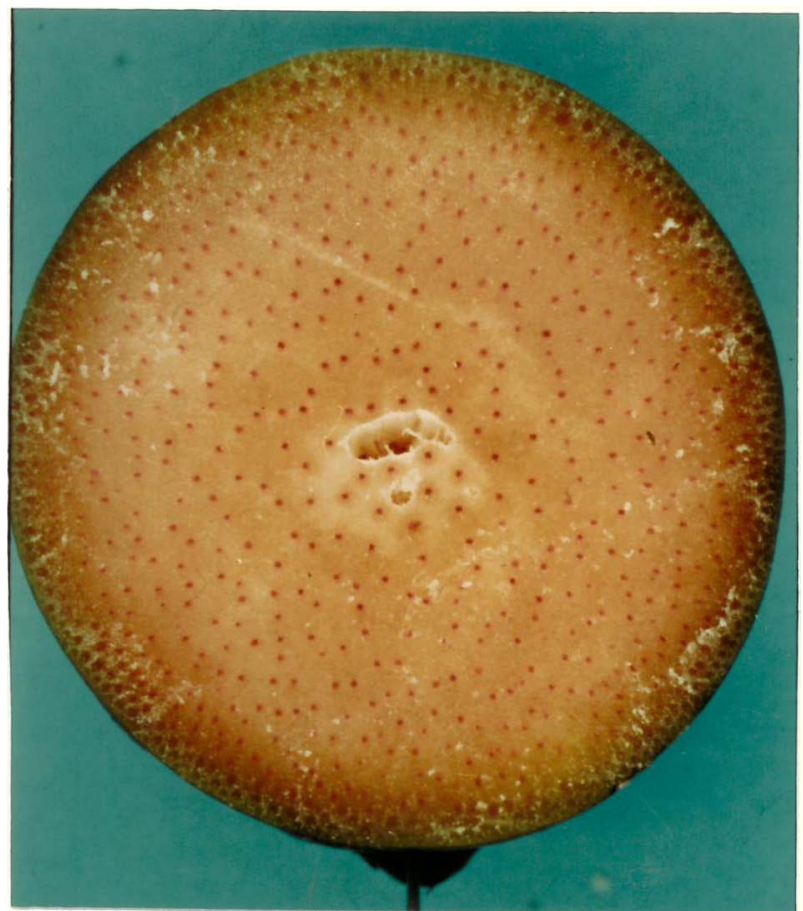

Figura 5 - Testemunha apresentando 660 vasos funcionais.

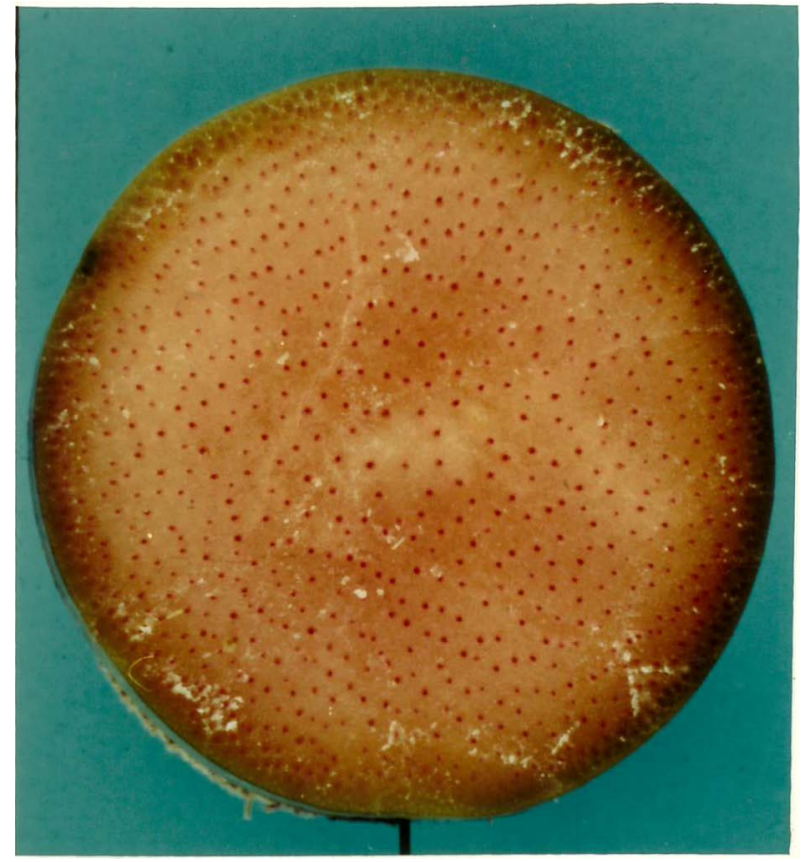

Figura 6 - Com Escaldadura das

Folhas apresentando 823 vasos funcionais. 
conclusão mais segura do comportamento destas duas varieda des e da distribuição da bactēria do RS dentro da touceira e dos colmos, pois as variações observadas levam a suspeita de haver colonização de forma irregular dentro de um único colmo e entre colmos da touceira infectada.

A correlação entre a vazão de água em colmos de cana-de-açūcar com EF e número de vasos funcionais mostrou-se positiva para as variedades CB41-76, "CB47-355, IAC48/65 e NA56-79. Porém a variedade IAC51/205 apresentou menor número de vasos funcionais e maior vazão quando comparados com a testemunha, provavelmente justificando as afirma ções de MARTIN e ROBINSON (1961) que o agente causal da EF, quando ocorre obstruções dos vasos do xilema por substāncias gomosas, pode causar a desintegração das paredes celulares do xilema, causando desvios para o fluxo de ägua.

Através da coloração dos vasos funcionais do xilema, foi possivel comprovar de forma direta que o trata mento térmico $\left(50,5^{\circ} \mathrm{C} / 2 \mathrm{~h}\right)$ não controla totalmente o RS, conforme se observa na figura 7 , a onde a parte central do colmo obtido de viveiro primārio após tratamento térmico, apresenta-se com os vasos do xilema obstruídos, devido à presença de ataque de RS, não permitindo a passagem do corante safranina. Esta foto evidencia outra possibilidade do uso do fluxômetro para o controle de qualidade de mudas de viveiros e avaliação da sua taxa de contaminação. Não fói encontrada na literatura nenhuma descrição de metodologia capaz de efetuar este controle usando-se equipamento simples e de custo bas tante reduzido. 
VARIEDADE CB41-76

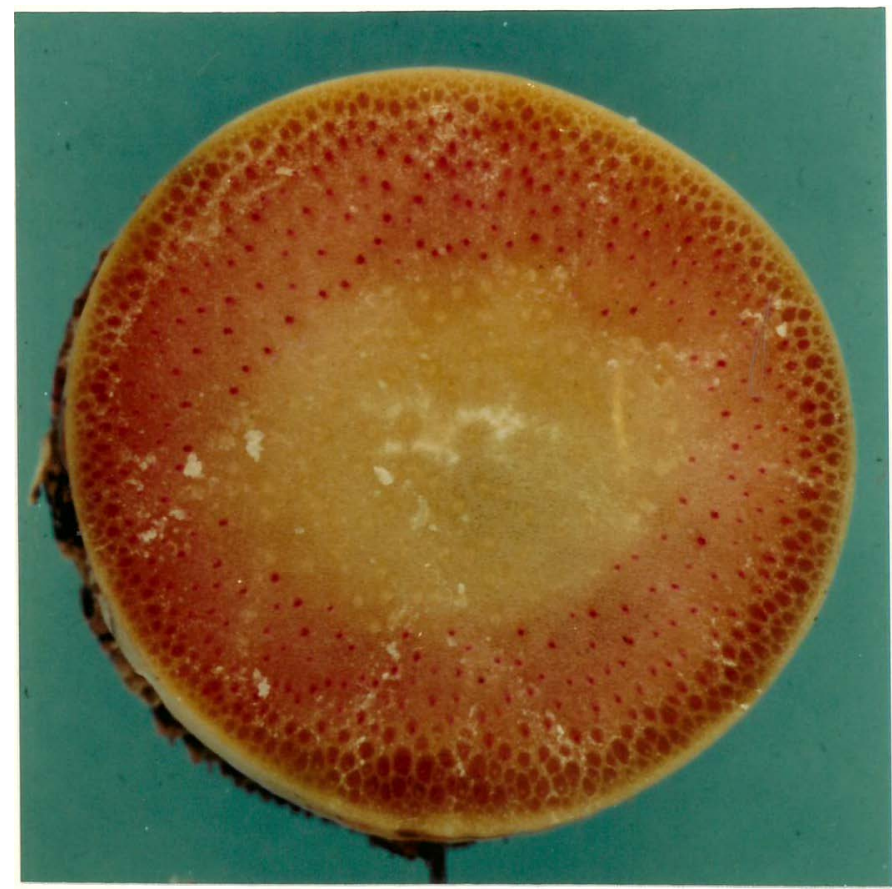

Figura 7 - Testemunha tratada ter micamente a $50,5^{\circ} \mathrm{C}$ por 2 horas mostrando a presença do Raquitis mo da Soqueira na ārea central da secção não colorida. 


\section{CONCLUSÕES}

Dos resultados obtidos no presente trabalho, podem ser tiradas as seguintes conclusões:

1. Existe diferença entre a vazão de āgua em colmos de canade-açūcar sadias e doentes com RS e por este mētodo é pos sível avaliar o nível de resisténcia das variedades quanto à esta doença.

2. As variedades CB47-355, IAC48/65 e IAC51/205 podem ser consideradas tolerantes e as CB41-76 e NA56-79 são consideradas suscetíveis ao RS pelo método da vazão de āgua em colmos de cana-de-açūcar.

3. 0 método de važão de àgua em colmos de cana-de-açūcar pos sivelmente é mais preciso do que o método da produção de colmos (kg/parcela) em microparcelas, na avaliação de níveis de resistēncia ao RS. 
4. O método de vazão de água em colmos de cana-de-açūcar não funciona para avaliação de resistência a EF.

5. O mecanismo de patogenicidade do agente causal do RS ē di ferente ao da $X a$.

6. A EF provavelmente pode interferir no método de avaliação de resistência ao RS, pela vazão de água.

7. Atravēs da coloração dos vasos funcionais do xilema é pos sivel visualizar as falhas do tratamento térmico no con trole do RS em viveiros. 


\section{LITERATURA CITADA}

ADSUAR, J. e J.H. LOPEZ-ROSA, 1962. Failure to transmit the causal agent of ratoon stunting disease of sugarcane through the soil. Journal of Agriculture of University of Puerto Rico, Rio Piedras, 46:87-90.

AKIBA, F., 1978. Isolamento, inoculação e sobrevivéncia de Xanthomonas albilineans e avaliação de resistēncia a esca] dadura das folhas em cana-de-açūcar. Piracicaba, ESALQ/USP, 97p. (Dissertação de Mestrado).

ANTOINE, R., 1957. A histo-chemical test for diagnosing ratoon stunting disease of sugarcane. $3^{3^{\text {eme }} \text { Congrés de la }}$ P.I.0.S.A., Tananarive, P. 155-160.

BAILEY, R.A., 1976a. Some observations on the bacterium associated with ratoon stunting disease of sugarcane. In: Proceedings of the 50 th South African Sugar Technologists'. Association, Durban, p. 60-64.

BAILEY, R.A., 1976b. Heat treatment and leaf scald. Sugarcane Pathologists' Newsletter, Aiea (17):14-16. 
BAILEY, R.A., 1977. The systemic distribution and relative occurrence of bacteria in sugarcane varieties affected by ratoon stunting disease. In: Proceedings of the 51 sh South African Sugar Technologists' Association, Durban, p.55-56.

BECHET, G.R., 1976. Ratoon stunting disease and rapid diagnostic techniques. Proceedings of the 50 th South, African Sugar Technologists' Association, Durban, p.4. (Separata).

CHEN, C.T.; M.J. CHEN e S.M. LEE, 1978. Studies on sugarcane ratoon stunting disease in Taiwan. I. Phase-contrast and electron microscopy of the small coryneform bacteria in the diseased sugarcane. Report of the Taiwan Sugar Research Institute, Tainan, (80):13-20.

CHEN, C.T.; S.M. LEE e M.J. CHEN, 1975. Small coryneform bacteria in ratoon-stunted sugarcane. Sugarcane Pathologists' Newsletter, Honolulu $(13 / 14): 6-8$.

DAMANN, K.E. Jr., 1976. A possible causal organism of ratoon stunting disease. In: Proceedings of the 5 th American Society of Sugar Cane Technologists', Baton Rouge, p. 53-55.

DAMANN, K.E. Jr. e K.S. DERRICH, 1976. Bacterium associated with ratoon stunting disease in Louisiana. Sugarcane. Pathologists' Newsletter, Aiea, (15/16):20-22.

DAMANN, K.E. Jr.; K.S. DERRICH; A.G. GILLASPIE Jr.; B.F. FONTENOT e J. KAO, 1977. Detection of the RSD-associated bacterium by serologically specific electron microscopy. In: Proceedings of the 18 th Congress International Society of Sugar Cane Technologists, São Paulo. p.433-437. 
DAVIS, M.J.; A.G. GILLASPIE Jr.; R.W. HARRIS e R.H. LAWSON, 1980. Ratoon stunting disease of sugarcane: isolation of the causal bacterium. Science, Washington, 210:1365-1367.

DOUGLAS, R.A., 1981. Correlação entre vazão de água e resistēncia ao raquitismo da soqueira em cana-de-açūcar. Piracicaba, ESALQ/USP, 57p. (Dissertação de Mestrado).

FARRAR, L.L., 1957. A chemical test for ratoon stunting disease of sugarcane. Phytopathology, Lancaster, 47:10.

FIFE, J.M. e I.E. STOKES, 1959. Amino acid changes: identify ratoon stunting disease. Sugar y Azucar, New York, 54:27-28.

FORBES, I.L. e K.C. LING, 1960. Particles associated with the ratoon stunting disease of sugarcane. Sugar Journal, New Orleans, $23(2): 15$.

GILLASPIE Jr., A.G., 1970. Evidence that ratoon stunting disease of sugar cane is caused by virus and not micoplasma. Phytopathology, Lancaster, 60:1448-1450.

GILLASPIE Jr., A.G., 1971. Ratoon stunting disease virus: problems in purification. In: Proceedings of the 1st American Society of Sugar Cane Technologists, Baton Rouge, p. $52-55$.

GILLASPIE Jr., A.G. 1978a. Ratoon stunting disease of sugarcane: serology. Phytopathology, Lancaster, 68:529-532.

GILLASPIE Jr., A.G., 1978b. An antiserumrto the ratoon stunting disease associated bacterium. Sugarcane Pathologists' Newsletter. Mauritius, (20):5-6. 
GILLASPIE Jr., A.G.; G. FLAX e H. KOIKE, 1976a. Relationship between numbers of diagnostic bacteria and injury by ratoon stunting disease in sugarcane. Plant Disease Reporter, Washington, $60(7): 573-575$.

GILLASPIE Jr., A.G.; J.E. IRVINE e R.L. STEERE, 1966. Ratoon stunting disease virus; assay technique and partial purification. Phytopathology, Lancaster, 56:1426-1427.

GILLASPIE Jr., A.G. e J.W. BLIZZARD, 1976. Some properties of the ratoon stunting disease agent of sugarcane. Sugarcane Pathologists' Newsletter, Aiea, (15/16):34-36.

GILLASPIE Jr., A.G.; M.J. DAVIS; R.W. HARRIS e R.H. LAWSON, 1981. Isolation and pathogenicity of the ratoon stunting disease bacterium. International Sugar Journal, Bucks, $83(995): 324-326$.

GILLASPIE, Jr., A.G.; R.E. DAVIS e J.F. WORLEY, 1973. Diagnosis of ratoon stunting disease based on the presence of a specific microorganism. Plant Disease Reporter, Washington, 57 (12): $987-990$.

GILLASPIE Jr., A.G.; R.E. DAVIS e J.F. WORLEY, 1975. Nature of the ratoon stunting disease agent. Sugar Journal, New orleans, 38: 7-10.

GILLASPIE Jr., A.G.; R.E. DAVIS e J.F. WORLEY, 1976b. Nature of the bacterium associated with ratoon stunting disease of sugarcane. Sugarcane Pathologists' Newsletter, Aiea, $(15 / 16)$ : $11-15$.

GILLASPIE Jr., A.G. e R.W. HARRIS, 1978. Screening for resistance to ratoon stunting disease-injury; the enzyme-linked immunosorbent assay. Sugar y Azucar, New York, 73(6):42-43. 
GILLASPIE.Jr., A.G. e R.W. HARRIS, 1979. Limitations of ELISA for detection of the RSD-associated bacterium in sugarcane and sudangrass. Sugarcane Pathologists' Newsletrer, Reduit (22):25-28.

HARRIS, R.W. e A.G. GILLASPIE Jr., 1978. Immunofluorescent diagnosis of ratoon stunting disease. Plant Disease Reporter, Washington, 62 (3):193-196.

HUGHES, C.G., 1958. Disease investigations: ratoon stunting disease. Annual Report Queensland Bureau of Sugar Experiment Stations, Brisbane, 58:68-95.

HUGHES, C.G., 1978. Diseases of sugarcane - a review. PANS, London, 24 (2):143-159.

HUGHES, C.G. e D.R.L. STEINDL, 1955. Ratoon stunting disease of sugarcane. Technical Communications. Queensland Bureau of Sugar Experiment Stations, Brisbane, 2:54.

HUGHES, C.G. e D.R.L. STEINDL, 1966. Some further developments in the study of ratoon stunting disease in Queensland. In: Proceedings of the 9 th Congress International Society of Sugar Cane Technologists. New Delhi, p. 1012-1022.

IRVINE, J.E., 1975. Factors affecting the expression of juvenile symptoms of the ratoon stunting diasease. In: Proceedings of the 4 th American Society of Sugarcane. Technologists, Baton Rouge, p. 109-113.

KAO, J. e K.E. DAMANN Jr., 1978. Microcolonies of the bacterium associated with ratoon stunting disease found in sugarcane xylem matrix. Phytopathology, Lancaster, 68:545-551.

KAO, J. e K.E. DAMANN Jr., 1980. In situ localization and morphology of the bacterium associated with ratoon stunting disease of sugarcane. Canadian Journal of Botany, Ottawa, $\underline{58}(3): 310-315$. 
KHURANA, S.M.P., 1972. Causal organisms of RSD. Sugarcane Pathologists' Newsletter, Durban (8):15.

LIAO, C.H. e T.A. CHEN, 1981. Isolation, culture and pathogenicity to sudan grass of a Corynebacterium associated with ratoon stunting of sugarcane and with bermuda grass. Phytopathology, Saint Paul, 71:1303-1306.

LIU, H.P., 1963. Studies on the ratoon stunting disease of sugarcane: purification of a nucleoprotein associated with diseased cane. Taiwan Sugar, Taipei, 10:9-11.

LIU, L.J.; A. CORTES-MONLLOR; K. MARAMOROSCH; H. HIRUMI; J.E. PEREZ e J. BIRD, 1974. Isolation of an organism resembling Xanthomonas vascuzorum from sugarcane affected by ratoon stunting disease. In: Proceedings of the 15sh Congress International Society of Sugar Cane Technologists, Durban, p. $234-240$.

LIU, L.J.; G. RAMİREZ-OLIVEIRAS; J.L. SERAPION e C.L. GONZALEZ-MOLINA, 1979. Further developments in the study of the ratoon stunting disease of sugarcane in Puerto Rico. Journal of Agriculture of University of Puerto Rico, Rio Piedras, $\underline{6} 3(2): 146-151$.

MARAMOROSCH, K.; B. PLAVSIC-BANJAC; J. BIRD e L.J. LIU, 1973. Electron microscopy of ratoon stunted sugar cane:

Microorganisms in xylem. Phytopathologische Zeitschrift, Berlin, $17: 270-273$.

MARTIN, J.P. e P.E. ROBINSON, 1961. Leaf scald. In: MARTIN, J.P., E.V. ABBOTT e C.G. HUGHES, eds. Sugarcane Diseases. of the World. Amsterdam, Elsevier, v.l, p. 79-107. 
MASUDA, Y., 1980. Aplicação da serologia na detecção de Xanthomonas albilineans em colmos de cana-de-açūcar. Piracicaba, ESALQ/USP, $111 \mathrm{p}$. (Tese de Doutoramento).

MATSUOKA, S., 1971. Elephant-grass, an indicator plant for ratoon stunting virus of sugarcane. Plant Protection. Bulletin-FA0, Rome, $\underline{9}(5): 110-115$.

MATSUOKA, S., 1972. Raquitismo da soqueira da cana-de-açūcar: diagnose da moléstia e estudos sobre o seu agente causal. Piracicaba, ESALQ/USP, 77p. (Tese de Doutoramento).

MATSUOKA, S., 1976. Recuperação da produtividade de variedades de cana-de-açúcar pelo tratamento térmico de toletes. Brasil. Açucareiro, Rio de Janeiro, $\underline{87}(5): 20-24$.

MATSUOKA, S., 1980. Microplots for screening sugarcane varieties for tolerance to ratoon stunting disease. In: Proceedings of the 17 th Congress International Society of Sugar Cane Technologists , Manila, p. 1628-1638.

PLAVSIC-BANJAC e K. MARAMOROSCH, 1972. Electron microscopy of the xylem of ratoon stunted sugarcane. Phytopathology, Lancaster, 62:498-499.

RICAUD, C.; S. SULLIVAN e J.C. AUTREY, 1976a. Presence of the RSD-associated bacterium in Mauritius. Sugarcane Pathologists' Newsletter, Aiea, 17:37-39.

RICAUD, C.; S. SULLIVAN e J.C. AUTREY, 1976b. Systemic infection of sugar cane by the bacterium associated with symptoms of ratoon stunting disease. Revue Agricole et Sucriere de I'llhe Mauricie, Réduit 5 $5(1 / 2): 159-162$. 
RICHARDSON, S.R., 1978. An improved method of xylem-sap extraction using positive pressure for the rapid diagnosis of ratoon stunting disease. Sugarcane Pathologists' Newsletter, Réduit, (21):17-18.

RISHI, H. e P. NATH, 1978. Association of the coryneform bacterium with ratoon stunting disease of sugarcane. Sugarcane Pathologists' Newsletter, Réduit, (20):9-10.

ROTH, G. e C. WHITEHEAD, 1965. Virus disease sugarcane. The South African Sugar Journal, Durban, 49:675-683.

SCHEXNAYDER, C.A., 1956. The effect of stunting disease of sugarcane on yields of cane and sugar in Louisiana, and the use of heat treatment for control. The Sugar Bulletin, New orleans, $34(22): 349-355$.

SCHEXNAYDER, C.A.", 1959. The use of a sugarcane "test plant" as a means of detecting the presence of ratoon stunting disease in sugarcane. In: Proceedings of the loth Congress. International Society of Sugar Cane Technologists ., Honolulu, p. 1068-1072.

SINGH, G.R., 1969. An indicator sugarcane variety for ratoon stunting disease. Current Science, Bangalore, $\underline{38}(9): 221$ 222.

STEIB, R.J. e D.M. TANTERA, 1970. Studies to determine the effect of tetracycline antibiotic on the ratoon stunting disease (RSD) of sugarcane. The Sugar Bulletin, New Orleans, 48:217-219.

STEIB, R.J. e I.L. FORBES, 1957. Johnson grass and corn as carriers of the virus of ratoon stunting disease of sugarcane. The Sugar Bulletin, New Orleans, 35:375. 
STEINDL, D.R.L., 1950. Ratoon stunting disease. In: Proceedings. of the 7 th Congress Internacional Society of Sugar Cane Technologists:, Brisbane, p. 457-465.

STEINDL, D.R.L., 1961. Ratoon stunting disease. In: MARTIN, J.P.; E.V. ABBOTT e C.G. HUGHES, eds. Sugarcane Diseases of the World. Amsterdam, Elsevier, v.l, p. 433-459.

STEINDL, D.R.L., 1974. Ratoon stunting disease history, distribution and control. In: Proceedings of the 15 th Congress International Society of Sugar Cane Technologists, Durban, p. $210-212$.

STEINDL, D.R.L., 1976. Pathology research development. New method of identifying ratoon stunting disease. The Eane Growers' Quartely Bulletin, Brisbane, 39(4):130-131.

STEINDL, D.R.L. e C.G. HUGHES, 1953. Ratoon stunting disease. The Cane Growers' Quartely Bulletin, Brisbane, 16:79-95.

STEINDL, D.R.L. e D.S. TEAKLE, 1974. Recent developments in the identification of ratoon stunting disease. In: Proceedings. of the Queensland Society of Sugar Cane Technologists $41 \mathrm{st}$ Conference. Brisbane, p. 101-104.

SUDO, S., 1980. Bactérias associadas ao raquitismo das soqueiras da cana-de-açūcar (Saccharum sp) e avaliação do capim elefante (Pennisetum purpureum Schum.) como indicadora. Piracicaba, ESALQ/USP, 86p. (Dissertação de Mestrado).

TANIMOTO, T., 1964. Microtome-slide projections for histological examination of sugarcane. Hawaiian Planters' Records, Honolulu, 57:119-132. 
TEAKLE, D.S., 1974. The causal agent of sugarcane ratoon stunting disease (RSD). In: Proceedings of the $15 \mathrm{sh}$. Congress International Society of Sugar Cane Technologists, Durban, p. 225-233.

TEAKLE, D.S.; D. KONTZE e J.M. APPLETON, 1979. A note on the diagnosis of ratoon stunting disease of sugarcane by negative-stain electron microscopy of the associated bacterium. Journal of Applied Bacteriology, 46(2):279-284.

TEAKLE, D.S.; J.M. APPLETON e D.R.L. STEINDL, 1978. An anatomical basis for resistance of sugar cane to ratoon stunting disease. Physiological Plant Pathology, New York, 12:83-91.

TEAKLE, D.S.; P.M. SMITH e D.R.L. STEINDL, 1973. Association of a small coryneform bacterium with the ratoon stunting disease of sugar-cane. Australian Journal of Agricultural Research, East Melbourne, 24:869-874.

TEAKLE, D.S.; P.M. SMITH e D.R.L. STEINDL, 1975. Ratoon stunting disease of sugarcane: possible correlation of resistance with vascular anatomy. Phytopathology, Lancaster, 65: $138-141$.

TOKESHI, H., 1980. Doenças da cana-de-açūcar. In: GALLI, F.; P.C.T. CARVALHO; E. BALMER; H. KIMATI; C.O.N. CARDOSO;C.L. SALGADO; T:L. KRUGNER; E.J.B.N. CARDOSO e A.B. FILHO, Manual. de Fitopatologia: doenças das plantas cultivadas, 2. ed., São Paulo, Ed. Agronōmica Ceres, v.2, p. 141-206.

TOKESHI, H.; A. SANGUINO e F. AKIBA, 1974. Xanthomonas albilineans, provável agente causal do raquitismo da soqueira e escaldadura de cana-de-açūcar. Brasil Açucareiro, Rio de Ja neiro, $\underline{84}(6): 28-40$. 
VALARINI, P.J., 1978. Avaliação da resistência ao raquitismo da soqueira pelo método da vazão de àgua em colmos de canade-açūcar. Piracicaba, ESALQ/USP, 78p. (Dissertação de Mes trado).

VALARINI, P.J. e H. TOKESHI, 1980. Factors that interfere in evaluation of ratoon stunting disease resistance by water flow in sugarcane stalks I. In: Proceedings of the $17 \mathrm{th}$. Congress International Society of Sugar Cane Technologists Manila, p. 1621-1627.

WEAVER, L.; D.S. TEAKLE e A.C. HAYWARD, 1977. Ultrastructural studies on the bacterium associated with the ratoon stunting disease of sugarcane. Australian Journal of Agricultural. Research, East Melbourne, 28:843-852.

WISMER, C.A., 1971. A sugarcane clone apparently immune to RSD. Sugarcane Pathologists' Newsletter, Sydney, (6):46.

WORLEY, J.F. e A.G. GILLASPIE Jr., 1975. Electron microscopy in situ of the bacterium associated with ratoon stunting disease in sudangrass. Phytopathology, Lancaster, 65:287-295. 